\title{
An Investigation into Geography Teachers' Use of Current Events in Geography Classes ${ }^{\mathrm{i}}$
}

\author{
Yavuz Değirmenci ${ }^{1, *}$, Ilhan Ilter ${ }^{2}$ \\ ${ }^{1}$ Faculty of Education, University of Bayburt, Bayburt, Turkey \\ ${ }^{2}$ Faculty of Education, University of Kahramanmaraş Sutcu Imam, Turkey
}

Copyright $\bigcirc 2017$ by authors, all rights reserved. Authors agree that this article remains permanently open access under the terms of the Creative Commons Attribution License 4.0 International License

\begin{abstract}
This study aimed to investigate the extent to which geography teachers use current events within the context of their geography instruction, their sources of information about current events, the methods and techniques they adopt while using current events in their teaching and the skills and values they expect their students to develop. The study, which was designed using a pattern of qualitative research methods, was conducted with 15 geography teachers determined by a maximum diversity sampling technique in Bayburt, Turkey. A semi-structured interview form was used to reveal the teachers' opinions. The data were analysed using the content analysis technique. The results showed that all of the teachers involved in the study followed current events when teaching geography. Some of the reasons why the teachers followed current events included the fact that geography science is considered as an axis course in life, providing permanent geographical knowledge for students and allowing them to gain a variety of perspectives. Furthermore, the sources that the teachers used most often when following current events were the internet use, newspapers and scientific publications and magazines. The teachers aimed to teach geography-specific skills, such as geographical inquiry, map reading and interpretation and field observations, to their students by using current events. However, the teachers did not employ student-centred activities while using current events and they transferred geography knowledge and skills to their students mostly through lectures, question-answer sessions and whole-class discussion.
\end{abstract}

Keywords Geography, Geography Education, Current Events, Current Events in Geography Teaching

\section{Introduction}

There is a constant interaction between man and the environment in which he lives. Individuals cannot be abstracted from the environment-medium they are in and from events that occur in this environment. Today, one of the ways in which individuals can live in harmony and peace with their surroundings is to understand, analyse and interpret the events that occur in their immediate and remote environments. Therefore, it is necessary to create an environment in the education process in which these skills can be developed in individuals. For example, teachers can transfer real-life examples from everyday life into their classrooms and associate such examples with their own subjects, providing their students with a different perspective. In this respect, to achieve these education objectives, it is necessary to integrate in-school and out-of-school experiences into the teaching process, transferring current and scientific events from everyday life to the classroom environment, thus helping students develop logical conclusions through learning about these events [1].

The younger generation's ability to adapt to the multidimensional societal structure of the twenty-first century, where change and transformation take place as quickly and intensely as possible, and their skills in analysing the global problems and complex situations they face are the most prominent characteristics of a contemporary individual [2]. Education plays an important role in training individuals who are the building blocks of the future. While preparing generations for life, education also provides the knowledge, skills and values necessary for individuals [3]. Therefore, the education process through which individuals prepare for life has to be intertwined with current events. In this context, associating content issues with current events in general education classes and basing teaching practices on current events and their outcomes are important in the educational process, while they are also necessary in academic and social life. Providing students with new knowledge, skills and attitudes can only be possible using this kind of teaching process $[4,1]$. In order for the information and experiences obtained during the educational process to be permanent, it is important that this information is associated with everyday events. For this reason, the education provided in the school environment 
should be aimed at helping to develop life skills [5]. This is due to the fact that, insofar as there is a connection between the knowledge and skills acquired in this process and real life, this information becomes permanent in the student's mind and makes it easier for the student to transfer the information to new situations $[6,7]$. The use of current events in general education classes not only enables permanence $[4,1]$, but also serves to create and develop students' social consciousness and, in particular, helps to increase students' global awareness [8]. In short, the use of current events contributes to the naturalisation and enrichment of learning experiences.

The kinds of current events that can be used in the classroom environment are extensive. Samples can be from both the local environment or from different parts of the world. Earthquakes, natural disasters, economic problems, social events or cultural transformations can be considered as daily events [4]. According to researchers, examining current events means individuals should be able to take lessons from those events and problems and this should help them take precautions against possible future problems. Students can achieve significant learning outcomes if certain problems in daily life are handled and discussed in the classroom. This is because concrete examples have a great influence on individuals' behaviour. Providing current examples in the learning process can develop a better understanding of the subjects at hand. The teacher's task in this process is to bring current events into the classroom and encourage students to analyse, evaluate and draw conclusions from these examples. Therefore, teachers should pay attention to their choice of current events, determine the appropriate methods and strategies for discussing the events and combine the examples with their own curriculum $[4,1]$.

\subsection{Use of Current Events in Content-area Classes}

Education provides an awareness of social situations and problems that students may encounter in daily life and offers students the ability to consider how to solve social problems [2]. For example, one of the most important reasons why content courses such as history, geography, citizenship and the arts are included in the school programme is to equip students with real-life experience and skills. Current events can therefore be used effectively in many content areas such as physics, chemistry, biology, science and social studies. Use the current events is considered to be pedagogically important in content-area classes; hence content-area teachers should integrate current events with their curriculum. For example, due to its content, geography is a discipline that is intertwined with life on both a local and global scale and it can include current events within its content. There is a mutual causal link between geography classes and current events. Students can understand how geographic information corresponds to life and they can gain different perspectives for their future lives by drawing conclusions from real-life examples.
According to Karabağ [9], geography is one of the basic sciences that deal with issues affecting individuals' lives. There is no doubt that a person lives in a certain environment and is influenced by his/her environment. For this reason, individuals perceive and learn the facts that they experience and relate to more easily. In other words, an individual establishes an active link between the phenomenon, events and beings around him/her and this promotes the development of a range of specific knowledge, skills and attitudes in the individual [10]. Geography aims to teach geographical awareness of one's country and the world, starting from the area in which students live so that students gain geographical skills that they can use effectively in their future lives, as well as acquire geographical values and national consciousness [11]. In order for geography education to be effective and productive, geographical information must correspond to students' daily lives and be associated with current events $[12,13]$. Individuals equipped with geographical knowledge can easily analyse and evaluate the regional movements of street vendors, location selection, traffic flow and farmers' or estate agents' land use strategies-behaviour appropriate to everyday life [14]. According to [15], the place and importance of geography lessons in students' daily lives depends on the extent to which current problems and proposals for solutions are reflected in the course content. Accordingly, geography education should teach individuals about the environment in which human beings live the characteristics of that environment and an understanding and perception of the universe. Therefore, it is necessary to illustrate the geography from within everyday life or to foreground the important elements of everyday life [16].

In geography education, it is not possible to isolate individuals from current events. This is because there are many issues that can be applied to geography education [10]. For example, when the subject of pressure is taught in the classroom, a current situation involving pressure can be discussed in the classroom environment. Contemporary examples could include the impact of geographical elements on tourism, rapid urbanisation and the problems of environment and migration - all of which can be brought into the classroom environment. For example, students could discuss how the current fog affects the strait and airway traffic or they could discuss current examples of natural disasters and their consequences in our environment and around the world. In this regard, geography topics are often up-to-date or related to current topics. As can be seen, environmental problems, disasters, human activities, urbanisation, migration, transportation, energy, agriculture, animal husbandry and settlement and sustainability are just a few such topics $[17,18,15]$. It is important that geography teachers provide their students with geographic concepts and facts with the help of various tools and methods by introducing current topics into the classroom environment. In this way, students will learn current information about geography subjects, as well as gain certain 
geography-specific knowledge and skills [17]. When examining the geography curriculum in relation to the use of current events in geography lessons, it should be noted that the curriculum emphasises that geography subjects should be associated with everyday life examples and that they must be taken into consideration in order to provide students with geographical skills. While the geography curriculum should be taught, students should also often discuss real-life problems and contradictory situations, and students should learn how to use the information and skills they acquire to solve such problems [19]. In developed countries where student-centred teaching is applied, geography courses are seen as important content areas that focus entirely on real-life situations, which in turn help students solve problems $[20$, 21].

Current events provide authentic learning experiences for students at all levels of learning and content areas. The use of current events greatly strengthens the content of the target units. The current issues or events chosen for discussion may not be directly related to current topics, but they can help students to think critically and make decisions and they can be important in helping students develop high-level skills, such as analysis and assessment of current events. The examination of current events requires both students and teachers to use one or more sources and place importance on information. When studying current events, students need to use a range of cognitive, sensory, research and communication skills $[22,23,24]$. Considering the promising results for student achievement in literature, it should be understood that the use of current events and teacher effectiveness are important factors in the development of students' social and environment consciousness. In order for students' geographical skills to continue to develop as their grade level increases, it is important to investigate the extent to which teachers are concerned with current events in their content area. This study mainly aimed to determine the extent to which geography teachers included current events in their teaching, their sources of information about current events, the methods and techniques they used while teaching current events and the skills and values they wanted to develop in their students.

\section{Method}

A phenomenological design was used as a qualitative research design that aims to investigate information about facts and experiences using a realistic and inductive method. According to Patton [25], a phenomenological design focuses on exploring the nature of a fact by learning about the experiences of people who are subjected to an examination in relation to a particular phenomenon or concept. As such, this study can be considered to be phenomenological research since it aimed to reveal to what extent geography teachers used current events in their classes (a), the sources they used when teaching current events (b), the criteria they used in choosing which current events to teach (c), the methods they used when teaching current events (d), the skills and values they wanted to develop in their students (e), the problems they encountered when teaching current events, the subjects they used for current events. The maximum variation sampling method was used to determine that the participants met certain criteria. A maximum variation sampling technique aims to determine whether there are common or shared phenomena among the various situations and to elucidate the different aspects of the research problem [26]. The criteria to participate in the research was that a teacher should have taught geography for at least one grade, including ninth, $10^{\text {th }}, 11^{\text {th }}$ and $12^{\text {th }}$, and that they had at least two years of teaching experience. As such, 15 geography teachers were recruited to participate in this research on a voluntary basis. The participants worked in secondary education schools in Bayburt, Turkey, during the 2016-2017 school year. The participants were informed about the purpose and sub-research questions of the study and they participated in interviews. As a qualitative approach requires a detailed description of the participants in the study group, when the personal information of the teachers participating in this study was examined, it was found that $52.7 \%$ of the teachers were male and $47.3 \%$ of the teachers were female. Of the participants, $58.5 \%$ of the teachers had graduated from a faculty of education, while $41.5 \%$ of the teachers had graduated from other social science faculties. When the teachers' teaching experience was examined, it was found that $22.5 \%$ of the teachers had between one and five years' experience, $40.1 \%$ had between six and 10 years' experience and $37.4 \%$ had been teaching for 11 years or more. When the teachers were asked whether they had a postgraduate education, it was found that only one teacher had a master's degree.

\subsection{Interview Form and Process}

The interviewing method was used in order to determine the participants' views on the practices used in the teaching of current events in geography instruction [27]. The data were collected using a semi-structured interview form. The purpose of qualitative interviews is to understand things that are not directly observable, such as participants' feelings, thoughts, ideas and behaviours [26]. While the interview form was being prepared, before the sample, pilot interviews were held with two geography teachers in three secondary education schools in Bayburt, Turkey. Several focused open-ended questions were developed depending on the flow of the interviews in the direction of the information obtained by means of the open-ended interview. In the pilot study, the answers given to the questions directly addressed to the relevant teachers helped the researchers explore several important points. For example, in the pilot study, the teachers were asked questions such as, "Do you follow any current events?", "Do you share these 
events with your students?" and "How often do you include current events in your classrooms?" According to the responses, they were then asked questions such as, "What activities or strategies do you use to teach current events in your classrooms?" The pilot interviews with the teachers were held in February 2017. The interviews lasted for an average of 15-20 minutes and were recorded on an audio recorder. The questions used and the data obtained from the pilot study were integrated with the results obtained as a result of the literature review and they were then developed $[28,22]$. During the data collection process, in order to gather data from the research sub-questions, the interviews were conducted on an appropriate day and time for the teachers and an interview plan was drawn up. The interviews were held in a teachers' room or outside classroom hours. During the interviews, each teacher was given enough time to share the practices they used for teaching current events. These interviews lasted approximately 20-25 minutes. The researchers briefed the teachers about the importance and sub-objectives of the research and had a short conversation with them to ensure more effective communication. The interviews took place during March 2017 and lasted 300 minutes. In all the interviews, the interview principles proposed by Fraenkel and Wallen [29] were followed and a voice recorder was used to avoid data loss.

\subsection{Data Analysis}

A content analysis technique was used to analyse the collected data in order to ascertain the answers to the research questions. Content analysis is a process of discovering the themes, patterns and categories present in the collected data [27]. The collected data were first converted into written form using a computer. The data were analysed using the following steps: (a) develop codes; (b) use codes to record data; (c) classify and compare codes under the headings; and (d) prepare visual presentations using defined topics, comparisons and classifications to investigate the research questions [30]. Accordingly, at the end of the data collection process, the audio recordings of the 15 interviews were analysed through the forward steps developed by Miles and Huberman [30]. The researchers (the authors) found the key concepts underlying the data they had collected, as well as the relationships among these concepts. The data were then read by the researchers and were defined into conceptual categories that outline the purpose of the research. After this step, a reliability rater was consulted to ensure the reliability of the data. For this, a copy of the interview records was delivered to the rater experienced in qualitative data coding and geography education. Miles and Huberman's [30] reliability formula $[$ Reliability $=($ Agreements $/$ Agreements + Disagreements $)$ $x$ 100] was used to calculate the compatibility between the researchers and the rater. The agreement inter-reliability between the coders was calculated as $86 \%$.

\section{Findings}

The findings are presented in a systematic way in line with the objectives of this study. The first of these aims was to discover "to what extent teachers were concerned with current events". The second aim was to ascertain "the criteria that teachers considered in selecting current events". The third was to determine "the resources they used to teach current events within their content area". The fourth aim was to find out "the methods teachers used when teaching current events". The fifth was to ascertain the "skills and values they hoped students would develop through their teaching of current events". The sixth aim was to determine "the problems they encountered when teaching current events" and the seventh was to discover the "geographical subjects and concepts in which current events were used". As a result, it was found that some of the teachers provided more than one application when they used current events in their classrooms. This is because the teachers' answers to the questions were included in more than one category, thus the sum of frequency in tables exceeds the number of participants.

\subsection{Distributions of the Teachers' Current Events Follow-up}

The first question directed to the teachers was: "Do you follow current events?" The answers given by the teachers are provided in Table 1.

Table 1. Teachers' current events follow-up status

\begin{tabular}{|c|c|}
\hline Category & $\mathrm{f}$ \\
\hline Yes & 15 \\
\hline No & 0 \\
\hline
\end{tabular}

As seen in Table 1, all teachers followed current events. The teachers also noted that all teachers should keep up with current events and that doing so was a teaching principle.

\subsection{Reasons Why Teachers Follow Current Events}

Table 2. Reasons why teachers followed current events

\begin{tabular}{|c|c|}
\hline Category & $f$ \\
\hline Persistence of knowledge & 6 \\
\hline $\begin{array}{c}\text { Geography science is a part of life } \\
\text { and daily life }\end{array}$ & 6 \\
\hline $\begin{array}{c}\text { Establishing a relationship between geographical subjects } \\
\text { concepts }\end{array}$ & 5 \\
\hline Facilitating students' understanding by concretising & 4 \\
\hline Reinforcing learning and making it effective & 4 \\
\hline Increasing interest in the course & 2 \\
\hline Promoting effective citizenship / creating love of homeland & 1 \\
\hline Increasing awareness of current events and environment & 1 \\
\hline Associating content topics & 1 \\
\hline Providing students with different perspectives & 5 \\
\hline
\end{tabular}


The second question directed to the teachers was: "Why do you follow current events?" When the teachers were asked about their reasons for following current events, their reasons were quite different. However, when their responses to this question were examined at large, it was found that they mostly stated "persistence of knowledge" and that "geography science is a part of life". The categories from the interviews are presented in Table 2.

When the distribution of the reasons for why the teachers followed current events was examined, the reasons that were reported most frequently were "persistence of knowledge", that "geography science is a part of life", to "establish a relationship between geographical subjects and daily life" and "facilitate students' understanding by embodying the concept", respectively. In addition, the teachers stated that they used current events to "reinforce learning" and to "increase students' participation and interest" in their classrooms. The teachers also shared that they followed current events in order to "increase students' awareness of current events and the environment", to "associate geography content topics" and to "provide students with different perspectives".

\subsection{Teachers' Criteria for Current Events Selection}

The teachers were asked: "What kind of criteria do you consider when choosing which current events to discuss when teaching your content?" The categories obtained from the interviews are given in Table 3.

Table 3. Teachers' criteria for selecting current events

\begin{tabular}{|c|c|}
\hline Category & $f$ \\
\hline Relation with topic & 12 \\
\hline Interesting & 6 \\
\hline Students' background knowledge & 4 \\
\hline Relevance to life & 3 \\
\hline Actuality of the event & 3 \\
\hline Students' requirements & 2 \\
\hline That the event was broadcast on TV and in the media & 2 \\
\hline Supporting concretising the content & 1 \\
\hline Establishing connection with different situations and facts & 1 \\
\hline That it is important for real life & 1 \\
\hline
\end{tabular}

When the opinions of the teachers were examined regarding their criteria for the selection of current events, the five most frequently shared choices were, respectively, "relation with the topic", "being interesting", "conformity with students' levels", "relevance to life" and "actuality of the event". Other responses from the teachers included, "supporting the embodiment of the content", "establishing connection with different situations and events" and "importance for social life".

\subsection{Sources Used by Teachers When Using Current Events}

Another question directed to the teachers in this study was: "Which sources do you use or which sources do you prefer to use when determining the current event to be used in the course?" The categories obtained from this question are given in Table 4 .

Table 4. Sources used by teachers when teaching current events

\begin{tabular}{|c|c|}
\hline Category & $f$ \\
\hline Internet (Web-based sources) & 11 \\
\hline TV- News & 11 \\
\hline Newspapers & 7 \\
\hline Science publications and magazines & 6 \\
\hline Videos & 5 \\
\hline Smart board & 3 \\
\hline Textbooks & 3 \\
\hline Documentaries & 1 \\
\hline Observation & 1 \\
\hline Movies & \\
\hline
\end{tabular}

The majority of the teachers stated that they used the internet (web-based sources) and TV news to follow current events and that they enriched their own teaching and students' understanding by bringing these events to the classroom environment. In addition, the teachers also expressed that they shared current events with their students by making use of newspapers and science publications and magazines. Less frequently mentioned sources were videos, smart boards, textbooks, documentaries, observations and movies.

\subsection{Methods and Techniques Used by Teachers When Teaching Current Events}

The teachers were also asked: "How do you bring current events into the classroom environment?" The categories are given in Table 5.

Table 5. The methods and techniques teachers used when teaching current events

\begin{tabular}{|c|c|}
\hline Category & $f$ \\
\hline Lecture method & 12 \\
\hline Question-answer method & 4 \\
\hline Whole class discussion & 4 \\
\hline Case study & 2 \\
\hline Six thinking hats & 1 \\
\hline Reciprocal questioning & 1 \\
\hline Argumentation & 1 \\
\hline Homework & 1 \\
\hline Interviews & \\
\hline
\end{tabular}

The majority of the participants stated that they used the lecture method when teaching many current events. However, teachers also preferred other methods. These were question-answer sessions and whole class discussion. According to the results, the majority of the teachers 
preferred the lectures orally opposed to traditional teaching methods. In other words, it was obvious that the method of direct instruction was the preferred method in geography instruction. Teachers placed less emphasis on the methods of case study, six thinking hats, reciprocal questioning, argumentation, homework and interviews. It was a promising finding that a majority of the teachers included current events while teaching their curriculum, but their use of passive teaching methods while doing so was also an indication of a traditional teaching style.

Student-centred methods and practices, such as case studies, six thinking hats, reciprocal questioning and interviews, promote active learning and support active social and cognitive participation, but it was found that the majority of the teachers did not use these methods.

\subsection{Skills Teachers Develop in their Students through the Teaching of Current Events}

The teachers stated 15 skills that, through teaching current events, they aimed to develop in their students that would help to improve their conceptual geography understanding. The teachers thought that children should achieve these skills to be successful in geography. According to the teachers, the use of current events helps students learn a variety of specific geographic concepts they will encounter and will make them aware of social and cultural diversity, as well as economic facts and generalisations that exist in both their environment and the world. Therefore, the teachers suggested that these skills should be developed in students through discussions about current events. The categories obtained from the interviews are given in Table 6 .

Table 6. The skills that teachers aim to develop in their students through current events

\begin{tabular}{|c|l|}
\hline Category & $f$ \\
\hline Geographical inquiry & 4 \\
\hline Field observations & 4 \\
\hline Comparison of patterns & 4 \\
\hline Geographic association of facts & 4 \\
\hline Make conclusions & 3 \\
\hline Increase environmental awareness & 3 \\
\hline Maps and graphs reading and interpretation & 3 \\
\hline Problem solving & 3 \\
\hline Perception of change and continuity & 2 \\
\hline Analysis of spatial skills & 2 \\
\hline Awareness of sustainable living & 1 \\
\hline Inquiry & 1 \\
\hline Building sets of spatial concepts & 1 \\
\hline Self-responsibility & 1 \\
\hline Time management & 1 \\
\hline
\end{tabular}

The majority of the teachers stated that they aimed to provide their students with skills of "geographical inquiry", "observation", "comparison of patterns", "geographic association of facts" and "make conclusions" through the teaching of current events. These skills were followed by "increase environmental awareness", "maps and graphs reading and interpretation" and "problem solving". The results showed that teachers tried to make their students achieve a certain set of skills outlined in the geography curriculum [19] by making use of current events as well as textbooks. The teachers also aimed to provide their students with other skills, including "perception of change and continuity", "analysis of spatial skills", "inquiry", "Building sets of spatial concepts", "self-responsibility", and "time management" through the use of current events.

\subsection{Values Teachers Develop in their Students through Teaching Current Events}

The teachers were also asked: "What values do you aim to provide to your students through bringing current events into the classroom environment?" The categories obtained from the interviews are given in Table 7.

Table 7. The values that teachers aim to develop in their students through teaching current events

\begin{tabular}{|c|c|}
\hline Category & $f$ \\
\hline Sensitivity to the environment & 5 \\
\hline Geographical consciousness & 2 \\
\hline Look to the future with confidence & 1 \\
\hline Predicting tomorrow & 1 \\
\hline A conscious future & 1 \\
\hline Holistic and different perspectives & 1 \\
\hline Sense of unity and togetherness & 1 \\
\hline Love of homeland and nation & 1 \\
\hline Empathy & 1 \\
\hline Respect for community and human & 1 \\
\hline
\end{tabular}

When the opinions stated by the teachers in Table 7 were examined, the teachers most emphasized the value category of "sensitivity to the environment". The teachers highlighted in particular the importance of current events in creating environmental awareness in their students. Several of the values on which teachers placed less emphasis included "geographical consciousness", "looking to the future with confidence", "predicting tomorrow", "a conscious future", "holistic and different perspectives", a "sense of unity and togetherness", "love of homeland and nation", "empathy" and "respect for community and human". 


\subsection{Problems Teachers Encounter When Teaching Current Events}

In this study, the teachers were asked: "When using current events, do you encounter any problems during and after instruction?" The results are given in Table 8 .

Table 8. Problems that teachers encounter in using current events

\begin{tabular}{|c|l|}
\hline Category & $f$ \\
\hline No problem & 4 \\
\hline Inadequate course hours & 3 \\
\hline Lack of geographical cause-effect relationship skills & 2 \\
\hline Lack of including current events & 1 \\
\hline The events of the last century can be dealt with & 1 \\
\hline Student disinterest & 1 \\
\hline Lack of map knowledge & 1 \\
\hline Students not following current events & 1 \\
\hline I do not know different methods and techniques & 1 \\
\hline Classroom management problems & 1 \\
\hline Inadequate equipment & 1 \\
\hline Not being able to find examples for each topic & 1 \\
\hline
\end{tabular}

As seen in Table 8 , the majority of the teachers stated that they did not encounter any problems when using current events. The teachers also stated "inadequate course hours" and "students' lack of ability to establish a cause-effect relationship" as problems. In addition, the other problems mentioned less frequently by the teachers were "lack of current events", "dealing with the events of the last century", "student disinterest", a "lack of map knowledge", "students not following current events", "not knowing different methods and techniques", "classroom management problems", a "lack of equipment" and "problems in determining a current event related to the topic".

\subsection{Geographical Subjects/Issues While Teachers Use Current Events}

When the question, "In what geographical subjects do you usually use current events in your lessons?" was directed to the teachers, they offered varied responses. The categories obtained are given in Table 9.

It was found that the teachers most regularly used current events related to three subjects in their geography lessons: "population and settlement", "natural disasters" and "environmental pollution", respectively. The teachers also included "economy and agriculture", "climate and weather events", "global warming" and "mines and energy resources". The topics less emphasised by the teachers were "ecosystem problems", "biodiversity", "internal and external forces", "transportation", the "geopolitics of Turkey", "neighbouring countries", "international organisations", "technology and science" and "treaties between countries".
Table 9. Geographical subjects in which teachers use current events

\begin{tabular}{|c|c|}
\hline Category & $f$ \\
\hline Population and settlement & 11 \\
\hline Natural disasters & 10 \\
\hline Environmental pollution & 8 \\
\hline Economy and agriculture & 7 \\
\hline Climate and weather events & 6 \\
\hline Global warming & 4 \\
\hline Mines and energy resources & 4 \\
\hline Agriculture and animal husbandry & 3 \\
\hline Tourism & 3 \\
\hline Glacier melting & 3 \\
\hline Local time & 3 \\
\hline Ecosystem problems & 2 \\
\hline Biodiversity & 2 \\
\hline Internal and external forces & 2 \\
\hline Transportation & 2 \\
\hline Turkey's geopolitics & 2 \\
\hline Neighbouring countries & 2 \\
\hline International organisations & 2 \\
\hline Technology and science & 1 \\
\hline Treaties between countries & 1 \\
\hline
\end{tabular}

\subsection{Teachers' Opinions on the Adequacy of Geography Textbooks in Terms of Current Events}

The final question posed to the teachers was: "Are geography textbooks sufficiently adequate in their use of current events?" The findings related to the teachers' answers are given in Table 10.

Table 10. Teachers' opinions on the adequacy of geography textbooks in terms of current events

\begin{tabular}{|c|c|}
\hline Category & $f$ \\
\hline Adequate & 13 \\
\hline Inadequate & 2 \\
\hline
\end{tabular}

While 13 out of 15 teachers noted that they did not think geography textbooks sufficiently included enough current events, the other two teachers stated that they found the textbooks to be adequate.

\section{Discussion}

The results showed that all of the teachers reported that they followed current events in their daily lives and in their content-area instruction. The teachers emphasised that current events should be used in the teaching and learning process. The teachers believed that there is a relationship between geography and current events. In their research, 
Haas and Laughlin [22] found that $90 \%$ of social studies teachers felt a strong need to include current events in their courses. According to this finding, teachers can achieve their content area objectives by including current events in the classroom at least once a week. These results suggest that current events can play a big role in geography teaching. This is because current events not only expand the scope of the objectives and achievements for geography courses, but they also support students' learning and social lives. Research has shown that a large majority of teachers are closely interested in current events and controversial issues [31, 32, 33, 34, 1, 35, 22, 36, 37]. According to Moffat [38], every teacher should know about current news and they should inform their students of current events in order to develop students' global and environmental awareness. Teachers who guide students on current events need to be aware of the importance of this issue.

Another finding in the study was that the teachers perceived geography science as a part of life and that geography subjects were connected with daily life. The teachers reported that they intended to develop their students' geographical awareness by taking advantage of many different current events in and out of school during their geography teaching. In constructivist geography teaching, teachers should often encourage their students to make comparisons with real-life problems and controversial issues, enabling students to use the knowledge and skills they have gained to solve the problems they encounter [11]. Geography and its content are not independent of current events. Many geography issues are closely related to current events [10]. Çolakoğlu [39] has emphasised that people generally obtain much of their information about current events from media sources, while Gedik [40] has noted that written and visual tools such as newspapers, magazines, TV and the internet are the main sources of news for people [39, 40].

The teachers were asked what kind of resources they used when following current events; the most preferred resources were the internet, TV news and newspapers, respectively. Some teachers reported that they took newspaper reports and photos about current events that caused extreme conditions into their classrooms and discussed with their students what natural events might cause these events. The teachers said that they asked their students to create semantic maps geographical concepts to emphasise the effect of extremes on natural developments. Similarly, two of the teachers who followed a current event on tourism activities in a magazine stated that they addressed its impact on environmental, cultural and economic development in their classes. As previous research has suggested, it was a promising finding that the teachers followed current events and made use of several printed and visual sources while following current events $[1,35,36]$. The use of real events in the classroom via sources such as newspapers, magazines and the internet makes lessons more fun and supports students' learning [41]. Teachers can encourage their students to participate by assigning work, projects or inquiry-based activities or they can encourage their students to follow current events by organising with them a news bulletin board containing current events [42, 43]. Bayır [44] found that the use of current events through various printed and visual materials increased students' interest and made the lesson more enjoyable, as well as positively influenced students' critical thinking and decision-making skills. Miller [45] has emphasised that the use of current events in the classroom improves students' discussion skills, as well as increases their attitudes towards social problems and furthers their academic achievements. In this study, the teachers were asked the reasons for following current events and they emphasised that current events may be effective in providing students with different critical perspectives. Students are likely to find interesting and interrelated events. Therefore, teachers can use current events for a better understanding of their content area goals. To reach the goals, teachers should engage students through many activities to develop their critical thinking skills and to increase students' democratic attitudes. Current events help teachers understand these theories and achieve their goals $[46,47]$. In particular, the teachers suggested that current events were related to target topics that were interesting and appropriate for the students' level. For example, three teachers stated that, as an example of an activity, they asked their students to write a report about the reasons why a current event took place. Supporting this finding, Gedik and Altun [48] has emphasised that current events and news should be at grade-level and contain clear, understandable and sufficient information. Researchers have found that current events are important and influential tools in the development of individuals' political, media, civil and critical literacy [49, 50, 51, 24]. Finn [53] and Pescatore [52] developed the formula "Critical Literacy + Current Events = Empowering Literacy" to emphasise the importance of current events in education. Within this formula, the more those students have a strengthened literacy experience with current events, the more they develop their critical literacy skills. In this way, students can develop skills to create new life-related information by discussing ideas about current events. At the same time, this can provide them with the ability to adapt their new knowledge and skills and gain cultural capital [54]. Finn [53] has suggested that teachers should go beyond the curriculum and give students the opportunity to think critically about events or controversial issues in social media, to explore different perspectives and to transfer their acquired knowledge to life.

The results showed that the teachers generally relied on the use of lecture, question-answer and discussion methods in the teaching of current events. Similar results also were found in Deveci's [1] and Gurkan's [35] study, which found that social studies teachers used question-answer, homework, discussion, case study and role-playing methods. Turner [47] has argued that students are highly successful in using multi-faceted learning experiences rather than passive 
learning. Similarly, Turan and Arslan [55] identified that $13 \%$ current events in the world. In the globalising world, the of primary-school teachers benefited from current events in order to gain universal and human values. Lastly, Ozşahin [56] investigated the advantages of using cartoons in geography teaching; he found that cartoons made it easy to develop an idea of current events for more than $70 \%$ of students. The results showed that geography teachers used several methods when teaching current events rather than just traditional methods. According to Cuban [57], instead of lecturing on current events or making students memorise facts from textbooks, activities based on active learning should be employed. For instance, before the teacher begins to discuss the lesson, the effectiveness of their teaching practices may increase if they explain current events and provide examples from life [58].

In this study, the teachers reported that they wanted their students to develop a variety of specific geography skills and values. The Geography Teaching Programme [19] aims to educate sensitive and conscious citizens about the environment within the programme's general objectives. The teachers aimed to provide their students with values such as sensitivity to the environment and geographical awareness through the use of current events. Eryllmaz [59] has pointed out that using current events in social studies classrooms increases students' sensitivity to social problems, while Aydın, Koçoğlu and Kaya [33] has emphasised that current events can be effective in developing students' sensitivity towards social events and facts. Geography teachers have espoused to their students the value of being sensitive to the environment, being respectful towards society and people and conscious of the future, along with nurturing a sense of unity and togetherness [11]. According to Ibret, Karatekin, and Avc1 [60], values in geography education help students understand the environment and the world they live in, making students aware that they are a part of mankind, ensuring that they have the necessary knowledge for economic development and can display sensitivity to the issues that concern the country and the world. Yel and Aladağ [61] have noted that teachers' use of actual evidence and current events in the process of value transfer are more effective in transferring values to students. When the problems encountered in the use of current events were examined, the teachers stated that they had problems because of reasons such as inadequacy of course hours, the inability to establish cause-effect relationships and students' apathy. In previous studies, teachers were found to have problems using current events due to similar reasons [1,35].

In today's world, where the amount information is constantly increasing, information in textbooks must be constantly updated. Geography is at the forefront of the lessons that must be meticulously studied in this field. Geographical information in geography textbooks should be renewed in accordance with the age and should be kept in line with the actuality principle. As Akınoğlu [12] has pointed out, in order for geography education to be effective, it is necessary to reconcile geographical information with most important task in recognising and understanding different nations, cultures and values falls to the science of geography. Therefore, geography teaching is effective in individuals' socialisation and in their becoming world citizens [62]. On the other hand, being able to understand complex relationships in today's world, to produce solutions to various problems of nature and man and to design a sustainable future can only be gained through conscious geography education [63]. Lastly, the study's result showed that the majority of the teachers thought that geography textbooks were not sufficient in terms of their inclusion of current events. The teachers stated that even outdated events that were no longer relevant were included in textbooks. Demirkaya and Tomal [64] found that secondary-school geography textbooks were not at the desired level in terms of actuality. The teachers emphasised the importance of events that would take place, especially in the near future. For this reason, it is important that the events in textbooks are up to date. A study by Çelikkaya and Yakar [41] indicated that not enough attention was paid to the selection of current topics and events in textbooks. In addition, the teachers stated that they included current events in their teaching of subjects such as population and settlement, natural disasters and environmental problems. Research has shown that social studies teachers mostly associate current events with topics such as disasters, political problems, international problems, human rights, citizenship, science, technology and environmental problems $[65,24]$.

\section{Limitations and Conclusions}

This study examined the extent to which geography teachers were concerned with current events, the sources they used to access information about current events, the methods they used while teaching current events and the skills and values they wanted to develop in their students. The results showed that the majority of teachers followed current events; but that they used passive learning methods and that they adopted a more traditional style when teaching current events. This study generally helped us to examine the basic teaching beliefs and practices that teachers reported in the teaching of current events in geography lessons. However, as in all other studies, there were some limitations that should be addressed in future research. First, the small sample size and unequal sampling of geography teachers prevented precise generalisations. This was because the sample of the study was limited to only 15 geography teachers. If future research could use a larger sample group, different findings may emerge. Second, there was no evidence of how the teachers used the methods and practices they mentioned in their classrooms. As the obtained data were not supported by classroom field observations and interviews, what was mentioned by the 
teachers may be limited to a self-report. In addition, the participants may not be completely sincere in their answers. In future research, it may be a good idea to observe teachers in their classrooms in order to validate the methods they said they had adopted in their content teaching area. In order for students to understand the environment and their relationship with it, it is necessary for them to read and observe current events that develop in both their society and in the world in general. Beginning from an early age, children should be educated to be responsible and democratic citizens. Through the use of a variety of resources, students have the opportunity to become more interested in news and current affairs and to learn to be an active member of the community $[7,66]$. In geography teaching, students can be made to analyse events and to make a deduction from such events. It has become necessary to prompt the active participation of students in the classroom, to teach current events to students in a concrete way and to take advantage of current events to make the lesson fun. However, in geography education, we cannot isolate individuals from current events. It is important for geography teachers to bring geographical concepts and facts to students with the help of various tools and methods by bringing current topics to the classroom environment in their lessons. In this way, students will gain geographical knowledge and skills, as well as learn up-to-date information about geography subjects. Teachers can create current event panels or current event bulletins for their students in class by making use of various sources. For example, teachers can improve students' awareness of the environment, develop their sense of social responsibility and develop various thinking skills, such as research, inquiry, critical thinking, empathy and problem-solving skills, by allowing students to acquire up-to-date, permanent and detailed information about the environment [67]. Welton and Mallan [68] have pointed out that students should be in a classroom where they can keep up with the news of the day. Teachers should include student-focused methods and alternative assessment practices appropriate to the constructivist learning approach in current event teaching. They can use methods and practices in which students are more active than traditional methods like lecturing. Teachers can also allow students to debate with their peers, allowing them to choose current events. In conclusion, all the results obtained from this study show that geography teachers should be good advisors to their students in current event teaching and use in their classrooms.

\section{REFERENCES}

[1] Deveci, H. (2007). Teachers' views on teaching current events in social studies. Educational Sciences: Theory \& Practice. 7 (1), 417-451.
[2] Kabapinar, Y. (2016). Kuramdan uygulamaya hayat bilgisi ve sosyal bilgiler. 2004 yilı programinda ölçme ve değerlendirme yeni yaklaşım ve yöntemler (ss. 339-349). Ankara: Pegem Akademi Yayıncılık

[3] Şişman, M. (2011). Eğitim bilimine giriş (16 bask1). Ankara: Pegem Akademi Yayınc1lık

[4] Binbaşıŏlu, C. (2004). Eğitimde günlük olaylar ve öğretimi. Çăgdaş Ĕgitim Dergisi, 315, 14-16.

[5] Arın, D. ve Deveci, H. (2008). Sosyal bilgiler dersinde güncel olayların kullanımının öğrenci başarısına ve hatırda tutma düzeyine etkisi. Elektronik Sosyal Bilimler Dergisi. 7(26), 170-185.

[6] Çoştu, B, Ünal, S. ve A. (2007). Günlük yaşamdaki olayların fen bilimleri öğretiminde kullanılması. Ahi Evran Üniversitesi Kırşehir Eğitim Fakültesi Dergisi, 8 (1),197-207.

[7] Smith, D.O. (1963). Current events in the intermediate grades of a modern elementary school (MS Thesis) Kean University. New Jersey.

[8] Ayas, A. ve Özmen, H. (1999). Asit-baz kavramlarını güncel olaylarla bütünleştirilme seviyesi: Bir örnek olay çalışması. III. Ulusal Fen Bilimleri Eğitimi Sempozyumu. KTÜ. Trabzon.

[9] Karabağ, S. (2007). Coğrafya ögrretmenlerinin mesleki sorumluluklarl. Kuram ve Uygulamada Coğrafya Eğitimi. (Edit. Karabağ, S. ve Şahin S.). Ankara: Gazi kitapevi.

[10] Doğanay, H. (2002). Coğrafya öğretim yöntemleri. Erzurum: Aktif Yayınevi.

[11] Ministry of National Education, (2011). Coğrafya dersi ögretim programı $(9,10,11$ ve 12 . siniflar). Talim ve Terbiye Kurulu Başkanlığg MEB Ders Kitapları Dizisi. Ankara.

[12] Akınoğlu, O. (2005). Coğrafya eğitiminin etkililiği ve sorunlar1. Marmara Coğrafya Dergisi, 12, 77-96.

[13] Karakuyu, M. (2010). Coğrafya ve hayat boyu öğrenme: Coğrafya eğitiminde kavram ve değişimler (Edit. Özey, R. ve İncekara, S.). Ankara.

[14] Taş, H.İ. (2010). Zihin haritaları, harita okuma becerisi ve görselleştirme. (Edit. Özey, R. ve Demirci, A.). Coğrafya ögretiminde yöntem ve yaklaşımlar. İstanbul: Aktif Yayınevi.

[15] Şahin, C. (2003). Ortaöğretim coğrafya müfredat programında temel sorunlar. Türk Coğrafya Kurumu Coğrafya Kurultayı Bildiriler Kitabı. Gazi kitapevi. Ankara.

[16] Akınoğlu, O. (2005). Yapılandırmacı öğrenme ve coğrafya öğretimi. Marmara Coğrafya Dergisi. 10, 73-94.

[17] Aydın, F. ve Güngördü, E. (2015). Coğrafya ĕgitiminde özel ögretim yöntemleri. Anakara: Pegem Akademi Yayıncılık.

[18] Değirmenci, Y. (2017). A sustainable future and geography education. studies on sustainability research. (Ed. Başar, E.E. and Bayramoğlu, T.). Lambert Academic Publishing. 175-187.

[19] Geography Course Curriculum,(2006). Coğrafya dersi ögretim programı. Ankara: Gazi Kitabevi.

[20] Arı, Y. (2010). Coğrafyayı neden çok boyutlu olarak tanımlama ve öğretmeye ihtiyaç vardır? (Edit. Özey, R. ve Demirci, A.) Coğrafya ögretiminde yöntem ve yaklaşımlar. Aktif Yayınevi. İstanbul. 
[21] İncekara, S. (2010). Coğrafya öğretiminde örnek olay yöntemi ve uygulanması. (Edit. Özey, R. ve Demirci, A.) Coğrafya Ögretiminde Yöntem ve Yaklaşımlar. İstanbul: Aktif Yayınevi.

[22] Haas, M. E., \& Laughlin, M. A. (2000). Teaching current events: Its status in social studies today. ERIC Number: ED440899

[23] Ord. J. E. (1972). Elementary school social studies for today's children. New York: Harper \& Row.

[24] Gedik, H.D. (2010). Güncel olayların ilköğretim sosyal bilgiler derslerinde kullanımı ve öğrenci görüşleri. Ahi Evran Üniversitesi Eğitim Fakültesi Dergisi. 11(2), 97-118.

[25] Patton, M. Q. (2002). Qualitative research \& Evaluation methods (3rd eds.). Thousand Oaks, CA: Sage Publication

[26] Patton, M. Q. (1990). Qualitative evaluation and research methods (pp. 169-186). Beverly Hills, CA: Sage Publication

[27] Yıldırım, A. ve Şimşek, H.(2011). Sosyal bilimlerde nitel araştırma yöntemleri. Ankara: Seçkin Yayınevi

[28] Deveci, H. (2005). Sosyal bilgiler dersinde gazete kullanımı. The Turkish Online Journal of Educational Technology. 4 (3), 159-166

[29] Fraenkel, J. R., \& Wallen, N. E. (1993). How to design and evaluate research in education (2nd ed.). New York: NY: McGraw-Hill.

[30] Miles, M. B., \& Huberman, A. M. (1994). Qualitative data analysis: An expanded sourcebook. (2 ed. J. Beverly Hills, CA: Sage

[31] Akdağ, H., Oğuz, R., Tatar, O. ve Subaşı, Y. (2014). Ortaokul sosyal bilgiler ders kitaplarının güncel olaylar bağlamında öğretmen görüşlerine göre değerlendirilmesi. Uluslararası Türk Ĕ̈itim Bilimleri Dergisi 2 (2), 49-65.

[32] Doğan, C. (2004). Sınıf öğretmenlerinin derslere ilişkin görüşleri ve tercih ettikleri öğretim yöntemleri (İstanbul örneği). Türk Eğitim Bilimleri Dergisi. 2 (2), 1-17

[33] Aydın, M. Koçoğlu, E. ve Kaya, A. G. (2016). İçerik olarak sosyal bilgiler dersinin güncellik ilkesi çerçevesinde ögretmen algılarına göre analizi. Uluslararası Sosyal Bilgiler Eğitimi Sempozyumu. Pamukkale Üniversitesi. 28-30 Nisan. Denizli.

[34] Çengelci, T. (2013). Sosyal bilgiler öğretmenlerinin sınıf dışı ögrenmeye ilişkin görüşleri. Kuram ve Uygulamada Eğitim Bilimleri. 13 (3), 1823-1841.

[35] Gürkan, B. (2009). Sosyal bilgiler eğitiminde güncel olaylar: ilköğretim Dördüncü ve beşinci sinıf ögretmenlerinin sosyal bilgiler Eğitiminde güncel olaylart ele alış biçimlerinin değerlendirilmesi (Yayımlanmamış yüksek lisans tezi). Çukurova Üniversitesi Adana.

[36] Taş, A. M. ve Özkaral, T. C. (2016). Sosyal bilgiler öğretmen adaylarının güncel olaylar ve derste kullanımına ilişkin görüssleri. Uluslararası Sosyal Bilgiler Eğitimi Sempozyumu. Pamukkale Üniversitesi. 28-30 Nisan. Denizli.

[37] Copur, A., \& Demirel, M. (2016). Turkish social studies teachers' thoughts about the teaching of controversial issues. JSSE-Journal of Social Science Education, 15(2), 80-95.
[38] Moffat, M. P., \& Oran, N. (1957). Sosyal bilgiler öğretimi. Maarif Vekâleti.

[39] Çolakoğlu, T. (2000). Sporun topluma yaygınlaştırılmasında medyanın etkisi (Güreş örneği) (Yayımlanmamış yüksek lisans tezi). Ankara Gazi Üniversitesi. Ankara.

[40] Gedik, H.D. (2008). Sosyal bilgiler ders kitaplarında güncel konular. TSA, 1, 117-134

[41] Çelikkaya, T. ve Yakar, H. (2015). Sosyal bilgiler programinda gazete, dergi ve internet haberlerinin kullanılmas1. Turkish Studies. 10 (3), 251-270.

[42] Ministry of National Education. (2005), Ilköğretim sosyal bilgiler dersi ögretim programı ve kllavuzu (4- 5.sınıflar). Ankara: Talim Terbiye Kurulu Başkanlığı Milli Eğitim Bakanlığı Yayınevi.

[43] Paykoç, F. (1987). Güncel olaylarla belirli gün ve haftaların öğretimi. B. Özer (Edit.), Sosyal bilgiler öğretimi (ss. 44-60). Eskişehir: Anadolu Üniversitesi Yayınları.

[44] Bayır, Ö.G. (2010). Sosyal bilgiler dersinde güncel olaylardan yararlanmanın ögrencilerin eleștirel düşünme becerilerine etkisi. (Yayımlanmamış yüksek lisans tezi). Anadolu Üniversitesi. Eskişehir.

[45] Miller, L. (2017), Current events in a civics classroom: Using problem-based learning to assess awareness of and attitudes towards current events. Studies in Teaching 2017 Research Digest. Action Research Projects Presented at Annual Research Forum. Winston-Salem, NC. Wake Forest University

[46] Sperry, C. (2006). Seeking truth in the social studies classroom: Media literacy, critical thinking and teaching about the Middle East. Social Education. 70 (1), 37-43.

[47] Turner, T.N. (1995). Riding the rapids of current event. Social Studies, 86 (3), 117-121.

[48] Gedik, H.D. ve Altun, A. (2008). Sosyal bilgilerde güncel olaylar ve medya okuryazarlığ . (Edit. Tay, B. ve Öcal, A.). Özel ögretim yöntemleri ile sosyal bilgiler öğretimi. Ankara: Pegem Akademi Yayıncilık.

[49] Tarhan, Ö. (2015). Sosyal bilgiler öğretmeni adaylarının politik okuryazarlığa ilişkin görüşleri. Akademik Sosyal Araştırmalar Dergisi, 3 (9), 649-669.

[50] Deveci, H. ve Çengelci, T. (2008). Sosyal bilgiler öğretmen adaylarından medya okuryazarlığına bir bakış. Yüzüncü Y Yl Üniversitesi, Eğitim Fakültesi Dergisi. 5 (2), 25-43.

[51] Biser, J. M. (2008). Current events and the classroom: An investigation into teachers' integration of current events in the secondary social studies classroom. Studies in Teaching 2008 Research Digest, 19.

[52] Pescatore, C. (2007). Current events as empowering literacy: For English and social studies teachers. Journal of Adolescent \& Adult Literacy. 51 (4), 326-339.

[53] Finn, P. (1999). Literacy with an attitude. Albany: State University of New York Pres.

[54] Anyon, J. (1981). Social class and school knowledge. Curriculum Inquiry. 11, 3-42.

[55] Turan, C. ve Arslan, S. (2016). İlkokul öğrencilerinde 
evrensel ve insani değerlerin Kazandırılma sürecinin, sınıf öğretmenlerinin görüşlerine göre değerlendirilmesi. International Journal of New Trends In Arts, Sports \& Science Education. 5 (1). 26-41.

[56] Özşahin, E. (2009). Karikatürlerle coğrafya öğretimi. Marmara Coğrafya Dergisi. 20, 101-121.

[57] Cuban, L. (1991). History of teaching in social studies. In J. P. Shaver (Ed.), Handbook of research on Social studies teaching and Laming A project of the National Council for the Social Studies (pp. 197-209). New York: Macmillan 97-209). New York: Macmillan.

[58] Güven, İ. (2004). Etkili bir öğretim için öğretmenden beklenenler. Milli Eğitim, 164, 127-141.

[59] Eryılmaz, Ö. (2015). Sosyal bilgiler dersinde güncel olaylardan yararlanmanin ögrencilerin sosyal problemlere duyarlılıklarına etkisi. Anadolu Üniversitesi (Yayınlanmamış yüksek lisans tezi). Eskişehir.

[60] Ibret, B. Ü., Karatekin, K. ve Avc1, E. (2015). Sosyal bilgilerde coğrafya öğretiminin değerler eğitimi açısından önemi. Milli Eğitim. 207,5-22.

[61] Yel, S., \& Aladağ, S. (2009). Sosyal bilgilerde değerlerin öğretimi. (Edit. Mustafa SAFRAN). Sosyal bilgiler öğretimi, (ss. 117-148). Ankara: Pegem Akademi Yayıncılık

[62] Atasoy, E. (2010). Genel coğrafya. İstanbul: Ezgi kitabevi.

[63] Öztürk, M, (2007). Coğrafya: Gelişimi, içeriği, eğitimi. (Edit.) Karabağ, S. ve Şahin, S. Kuram ve Uygulamada Coğrafya Ĕ̆itimi. Ankara: Gazi Kitapevi

[64] Demirkaya, H. ve Tomal, N. (2002). Lise coğrafya ders kitaplarının değerlendirilmesi ve sorunlara yönelik çözüm önerileri. Marmara Coğrafya Dergisi. 5, 153-169.

[65] Bayır, Ö.G. (2010). Current events in 4th and 5th grade primary education social studies program. Procedia Social and Behavioral Sciences. 9, 923-928.

[66] Tomal, N., Karadeniz, C., \& Demirkaya, H. (2008). Gazete haberlerinin coğrafya ögrretimindeki önemi. Ahi Evran Üniversitesi Kırşehir Eğitim Fakültesi Dergisi, 9 (1), 73-85.

[67] Gökçe, N. (2009). Çevre eğitiminde gazetelerden yararlanma. Uluslararası Sosyal Araştırmalar Dergisi, 2(6), 251-265

[68] Welton, D. A., \& Mallan, T. M. (1999). Children and their world: Strategies for teaching social studies. New York: Houghton Mifflin Company.

\footnotetext{
i This paper was presented as an oral presentation in the International Symposium on Social Studies Education VI (May 04-06, 2017) in Eskisehir, TURKEY
} 